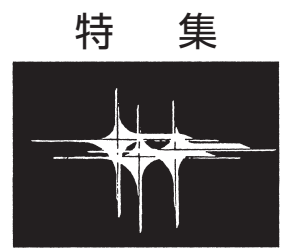

\title{
特集：ISO/TC 198(ヘルスケア製品の滅菌)に因んだ最近の話題
}

\section{化学的インジケータに関する話題－ISO/TC 198 の立場から}

藤 澤 俊 樹*

\section{1. 化学的インジケータの最近の話題}

1 ) 化学的インジケータのー般的要求 事 項 (General requirements) ISO 11 140-1 の改訂について

2014 年 11 月に ISO11140-1 : 2014-11-01 ${ }^{1)}$ が 第 3 版として発行された. 主な改訂は下記の通 りである.

(1)化学的インジケータの分類に用いる用語がク

ラスからタイプに変更となった.

化学的インジケータ (以下 CI) の一般的要 求事項は, 1995 年に第 1 版 $^{2}$ が作成されて以来, 2005 年に第 2 版 ${ }^{3)}$ に改訂されたが基本的に大き な改訂はおこなわれなかった。しかし，この間 クラス 6 インジケータが生物学的インジケータ の代用になるという誤った風潮が世界的に蔓延 した経緯があり，第 3 版の改訂に際しては米国 を中心にクラス分類の見直しの要望が強く, こ の点が改訂の大きなポイントとなった.

一方我が国においては, 日本医療機器学会発 行の「医療現場における滅菌保証のガイドライ ン 2005$\rfloor^{4)}$ が 2000 年版と比較して滅菌バリデー ションの将来的な導入を視野に入れ ISO を基 に大幅に改訂された，CIの章においても ISO 11140-1 の最新版を基に改訂された. クラス分 類（クラス $1 \sim 6$ ）に関しては, 医療現場にお ける滅菌保証のガイドライン $2010^{5}$ 改訂時も 2005 年版が踏襲され, 医療機関・滅菌委託業 者等においてもこのクラス分類は, 全国的に浸

* (株)サクラクレパス
透していた状況であった.

米国を中心とするクラス分類の改訂案は, ク ラス 1 (Process indicators) は現状維持とし, クラス 4〜6を一括して Multi-variable indicators とする案であった（この案は 1995 年に第 1 版 が作成された時点で討議された米国案と同等). これに対して欧州を中心に多数の国は，反対を 表明し Bowie-Dick テストに用いるテストパッ クがダブルスタンダードになった時を彷彿させ る混沌とした状況となった。ここで欧米の相反 する意見をハーモナイズさせるのが日本の意見 でありコメント提出の依頼があった。

この討議（2011 年 10 月）は, ISO 全体会議 の場ではなくWG 6 （CI の作業部会）の中間 会議の場であり急な依頼であったため, CI の 主査としてWG 6 国内検討委員の複数の委員 の意見もヒアリングして我が国の現状を下記の ように伝えた。

交日本としては現在のクラス分類を存続して欲 しい. その理由として,

(1)化学的インジケー夕の日本工業規格であ る JIS T 0831：2012*1 は, ISO11140-1： 2005 をべースに来年（この時点では 2012 年) 出版される.

(2)「医療現場における滅菌保証のガイドライ ン 2010」は, ISO11140-1：2005を踏襲し ている.

(3) ISO/JIS 規格準拠「ヘルスケア製品の滅 菌及び滅菌保証」改訂版は, ISO11140-1： 2005 を踏襲している.

日本では現在のクラス分類が広く浸透してお 
表 1 Categories according to intended use

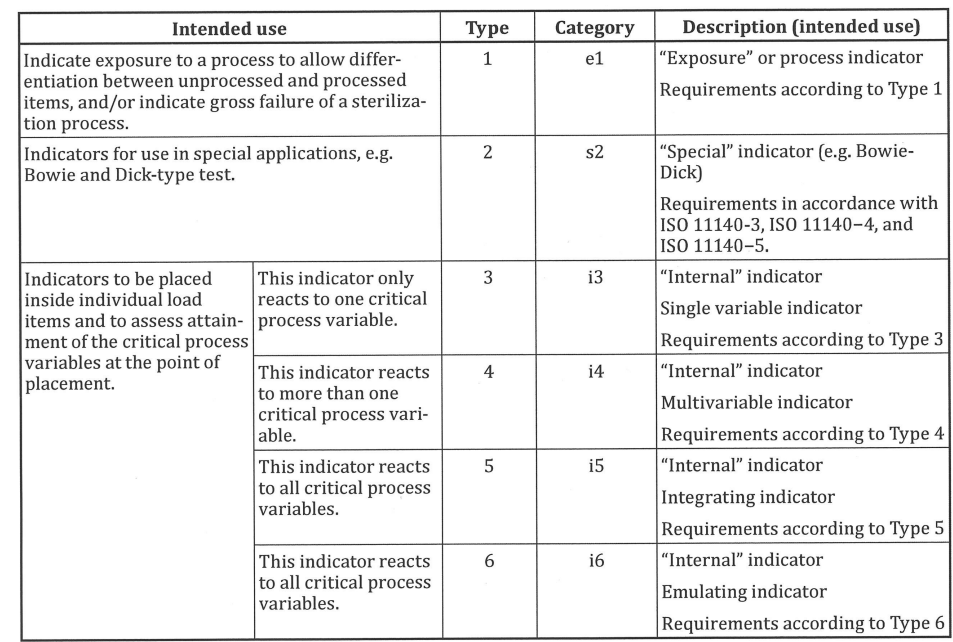

り, クラス分類の変更は使用者に混乱を招く.

以上 Japanese proposal として提出した.

*1後に正式名「ヘルスケア製品の滅菌一ケミカ ルインジケーター 第 1 部 :一般的要求事項 JIS T 11140-1 : 2013 (ISO 11140-1 : 2005) として発行

後にWG 6 の convener である Mr. Bancroft にお聞きしたところ，この Japanese proposal はクラス分類の現状維持に効果はあったようで ある。

現状のクラス分類を維持した ISO 11140-1： 2005 の改訂は, 翌年 (2012 年 4 月) の全体会 議（パリ）で採決され賛成 18 か国, 反対 7 か 国の $2 / 3$ 以上の賛成で承認され, DIS (Draft for International Standard）のステージに上 がった ${ }^{6)}$. その後系統的な改訂作業を経て最終 的に 2014 年 11 月第 3 版として発行された。 ンジケータの分類についての最終的な妥協案と して，クラスという用語がCI に序列をつけて いるように捉えられるのでタイプという用語に 変更された。また, 蒸気滅菌用タイプ5インジ ケータの試験条件が, ISO 11140-1：1995の条 件に戻った。詳細は, 医療現場における滅菌保 証のガイドライン $2015^{7)}$ を参照のこと.

(2)使用用途に基づく情報として，カテゴリーが 追加された.

・タイプ1は “Exposure” or process indicator と外部用用途が明確化となった. カテゴリー： e 1 と表示.

・タイプ2は “Special” indicator (e. g. BowieDick）と特定の試験用途が明確化となった. カテゴリー：s 2 と表示.

・タイプ 3〜 6は “Internal” indicator と内部 用挿入用用途が明確化となった. カテゴリー： i $3 \sim 6$ と表示. 表 1 を参照のこと.

(3) CI 製造業者が設計し, 検証する規定值 (stated value）は, 医療機関等の使用現場では再現 されないことが追記された。

規定值（stated value 以下 SV）および合格条 件 /不合格条件を理解するにあたり, CI の要求 性能は, ISO $18472^{8)}$ で規定される CI 評価装置 (chemical indicator evaluating resistometer : CIER）を用いて処理された際の值であることを 予め理解することが重要である. CIER は, CI を評価することを目的とした専用の装置であり， 医療機関で使用される滅菌器とは缶体容積, 滅 菌工程のダイアグラムが異なっており, 曝露工 程以外で殺菌効果がなるべく生じないように短 時間での滅菌剤の給排気が可能となっている. さらに, その際, CI は無包装で処理され, 他の 積載物の無い状態で評価される。したがって, 医療機関で一般的に使用される滅菌器を用いた 場合の合格条件と, CIER を用いた場合の SV は通常異なるため, 使用にあたっては検証をお こない, 運用方法を決めることが望ましい（ $)$. このような検証が実施困難な施設は, 自施設の 
(56) 医機学 Vol.86, No.3 (2016)

表 2 Test and performance requirements for Type3 and Type4 indicators

\begin{tabular}{|c|c|c|c|c|c|}
\hline Sterilization process & $\begin{array}{l}\text { Test } \\
\text { pointa }\end{array}$ & Test time & Test temperature & $\begin{array}{c}\text { Sterilizing agent } \\
\text { concentration } \\
\mathrm{mg} / \mathrm{l} \\
\end{array}$ & $\begin{array}{c}\text { RH } \\
\%\end{array}$ \\
\hline \multirow{2}{*}{ Steam } & 1 & SV & SV & & \\
\hline & 2 & $-25 \%$ & $-2{ }^{\circ} \mathrm{C}$ & & \\
\hline \multirow{2}{*}{ Dry heat } & 1 & SV & SV & & \\
\hline & 2 & $-25 \%$ & $-5^{\circ} \mathrm{C}$ & & \\
\hline \multirow{2}{*}{ Ethylene oxide } & 1 & SV & SV & SV & $>30$ \\
\hline & 2 & $-25 \%$ & $-5^{\circ} \mathrm{C}$ & $-25 \%$ & $>30$ \\
\hline \multirow{2}{*}{$\begin{array}{l}\text { Low temperature } \\
\text { steam and formalde- } \\
\text { hyde }\end{array}$} & 1 & SV & SV & SV & \\
\hline & 2 & $-25 \%$ & $-3^{\circ} \mathrm{C}$ & $-20 \%$ & \\
\hline \multirow{2}{*}{$\begin{array}{l}\text { Vaporized hydrogen } \\
\text { peroxide }\end{array}$} & 1 & SV & SV & SV & \\
\hline & 2 & $-25 \%$ & $-3{ }^{\circ} \mathrm{C}$ & $-20 \%$ & \\
\hline
\end{tabular}

滅菌条件と使用する CI の SVをできるだけ整 合させること及びCI 製造業者に一般的に使用 される滅菌器を用いた場合の合格条件に関する 情報（通常 SVより早い時間で合格する）を入 手することが望ましい.

付随してタイプ 6 インジケータに用いられて きた“cycle verification indicators”（工程検証 インジケータ)というセンテンスが削除された. 原文は下記の通りである。

emulating indicators の ISO 本文（第 2 版との 比較)

Second edition : 2005-07-15

4.7 Class $6:$ emulating indicators

Emulating indicators are cycle verification indicators which shall be designed to react to all critical variables for specified sterilization cycles. The SVs are generated from the critical variables of the specified sterilization process.

Third edition : 2014-11-01

4.7 Type 6 : emulating indicators

An emulating indicator shall be designed to react to all critical process variables for specified sterilization processes. The SVs are generated from process variables of sterilization processes as specified in International Standards ISO 11135, ISO 11137 (all parts) and ISO 17665 (all parts), or by regulatory agencies (see Clause 13). よってタイプ 6 (クラス) インジケータは, $\mathrm{SV}$ 条件のみ限定的にしか使用出来ないという 一部の誤った解釈を解説した文献等が見受けら れたがそれらは無効となった。

(4)過酸化水素蒸気滅菌用インジケータにタイプ 3 及び 4 が追加

要求される性能 (時間, 温度, 濃度の精度) は, 低温蒸気ホルムアルデヒド滅菌と同等で $\mathrm{E} O \mathrm{O}$ 滅 菌より厳しい規格となっている。 また過酸化水 素用試験評価装置は, 過酸化水素濃度が試験中 に安定性に欠けることが指摘されており製品に ラベリングできる評価が可能か否か今後の課題 となる.

ISO 11140-1：2014 に記載されている各滅菌 法の夕イプ 3,4 インジケータの要求性能は表 2 を参照のこと.

\section{2）ホロ一型デバイスについて}

クラス 2 及びホロー型デバイスを含む (process challenge device 以下 PCD）の規格が, CD (Committee Draft) として初出したのが200805-15で下記のタイトルであった.

Sterilization of health care products -Chemical indicators- Part 6: Class2 indicators and process challenge devices for use in performance testing for steam sterilizers

2014 年 12 月までWG 6 においてホロー型デ 
バイスの試験内容につきその都度プロトコール を検討し, 各国で長期間研究を実施した ${ }^{9 \sim 12)}$. しかし，EN 867-5に基づくホロー型デバイス は, 湿熱処理時の熱膨張のため, 規定されたサ イズ/形状が維持できないため蒸気滅菌に適し ていない, ということが結論付けられた. ホロー 型デバイスは, 約 6 年間かけてもその有効性 の科学的根拠が検証出来なかったことを受け, 2014 年 12 月 1 日のニューオリンズでの WG4, WG 6 ジョイント会議において「ISO 規定に基 づく討議時間切れ（5 年以上費やしている）」 と結論づけ一旦協議が中断された ${ }^{13)}$.

なお，ISO 制定に際してはウィーン合意（国 際レベルで業務を 2 度おこなわずに済むように 制定されている CEN：欧州規格が存在すれば ISO 委員が検討する）が設定されている. 今回 は EN 867-5；2001 Non-biological systems for use in sterilizers. Specification for indicator systems and process challenge devices for use in performance testing for small sterilizers Type B and Type S を基に缶体容積 $54 \mathrm{~L}$ 以 下の小型滅菌器用として新たな作業ドラフト (WD : Working Draft) ISO/WD 11140-6 $6^{14)}$ が 2015 年 2 月 7 日に発行された（CD にステージ アップさせる投票締切りが 2015 年 5 月 7 日の 3 か月投票)。この ISO/WD 11140-6 に対する コメントを作成するため, WG 6 国内検討委員 会を 2015 年 4 月 8 日に開催して長年討議され た PCD に関する情報を共有し日本のコメント を提出した ${ }^{15)}$. 詳細は割愛するがホロー型デバ イスについては小型滅菌器での使用に限定する ことを強く要望した.

上記のような背景・根拠に基づき，医療現場 における滅菌保証のガイドライン 2015 におい て CI の章及び生物学的インジケータの章にホ ロー型デバイスについては下記のように記載し た。

・ホロー型デバイスは蒸気滅菌器 (EN 規格に おいて規定されるチャンバー容積 60 リット ル以上の大型蒸気滅菌器) に対して, 運転時 適格性確認実施時あるいは, 少なくとも年 1 回実施を考慮してもいい蒸気浸透テストと規 定されている (ISO/TS 17665-2) ${ }^{16)}$.

\section{P139 11.1.4 使用方法より一部抜粋}

補足であるが PCD の国際的定義に基づき， 上記の蒸気浸透テストに用いるホロー型デバ イスは, PCDの範疇には適合しないためデ バイスという用語を用いている.

・このようなホロー型デバイスを用いる蒸気浸 透テストはボウィー・ディックテストの代替 テストや工程モニタリングとして用いない.

P133 10.1.3（2） 5）より一部抜粋

以上のように現存規格に採用されている以外 の用途の妥当性／適格性についての科学的根拠 は無く, 国内に打けるホロー型デバイスの利用 状況は適正とは言えない. ホロー型デバイスの みでは滅菌可否判断は不可能でありコストダウ ン優先で誤った選択をしている現状をWG 6 国内検討委員会では危惧している.

\section{2. 化学的インジケータの今後の動向}

(1) WD から 2015 年 8 月 22 日に CD にステージ アップし 2016 年 3 月 23 日に Ver.5 の CD とし て配布されたISO/CD-5 11140-6 Sterilization of health care products -Chemical indicatorsPart 6: Type2 indicators and process challenge devices for use in performance testing for small steam sterilizersの継続討議.

ホロー型デバイスは, PCD として製品化 する場合次の表示 (小型滅菌器用) が必要と なることで討議中である。

The alternative hollow device shall be clearly and permanently marked with the symbol :

\begin{tabular}{|c|}
\hline SMALL STEAM STERILIZERS \\
HOLLOW \\
ISO 11140-6 \\
\hline
\end{tabular}

なお，米国医科器械振興会 (AAMI) の繊維 質テストパック (16 枚の木綿製タオルパック ${ }^{17)}$ で代表されるポーラス型 PCD の使用に際して は滅菌器の容量に制限はない.

The alternative porous shall be clearly and permanently marked with the following information :

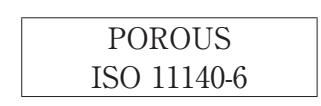


(2) ISO 18472 Sterilization of health care products -Biological and chemical indicatorsTest equipment $の$ 第 2 版 ISO/CD 18472 : 2015-02-09 の継続討議.

(3) Bowie-Dick テストパックの 3 規格 ISO 11140-3 : 2007 Sterilization of health care products -Chemical indicators- Part 3 : Class 2 indicator systems for use in the Bowie and Dick-type steam penetration test

IS0 11140-4 : 2007 Sterilization of health care products -Chemical indicators- Part 4 :

Class 2 indicators as an alternative to the Bowie and Dick-type test for detection of steam penetration

ISO 11140-5 : 2007 Sterilization of health care products -Chemical indicators- Part 5 :

Class 2 indicators for Bowie and Dick-type air removal tests の改訂討議.

尚, WG 6 国内検討委員会は下記のメンバー で構成されている。（順不同・敬称略）

氏名所属

藤澤 俊樹* (株)サクラクレパス

上寺 祐之 東京大学医学部附属病院 手術部

橋本章 (株ウドノ医機 研究開発部

山際 裕一 (株)ップ 品質保証本部

木村登 スリーエムジャパン(株へルスケ アカンパニー 技術本部 感染管 理製品技術部

浅岡 伸太 サクラ精機(侏) 洗浄滅菌機器事 業本部 開発部

丹羽由輝代 日油技研工業(侏)研究開発部

城之内幸宏 サクラ精機(株教育センター

高橋＼cjkstart治 サクラエスアイ(株)

*主査

\section{文 献}

1) ISO 11140-1 : 2014, Sterilization of health care products -Chemical indicators- Part1 : General requirement.

2) ISO 11140-1 : 1995, Sterilization of health care products -Chemical indicators- Part1 :
General requirement.

3 ) ISO 11140-1:2005, Sterilization of health care products -Chemical indicators- Part 1 : General requirement.

4）医療現場における滅菌保証のガイドライン 2005 : 日本医療機器学会

5 ）医療現場における滅菌保証のガイドライン 2010 : 日本医療機器学会

6 ) ISO/TC 198 N1004 Brief report of the meeting of ISO/TC 198/WG 6, Chemical Indicators, 16-17 April 2012

7 ）医療現場における滅菌保証のガイドライン 2015 : 日本医療機器学会

8) ISO 18472 Sterilization of health care products -Biological and chemical indicatorsTest equipment

9 ) Muller L. Monitoring Sterilization Processes -Value of Process Challenge Devices According to EN 867-5. Central Service $2010 ; 18$ (6) : 408-409.

10) Esen S, Tessarolo F, Hermsen R.J. van Doornmalen J.P.C.M. Current reference devices for hollow instrument loads as defined in standards are not a valid steam penetration test. Central Service 2012 ; 20 (4) : 256-260.

11) ISO/TC198-WG6 N0283 ISO/TC 198 WG6 N283 11140-6 Test Protocol

12) ISO/TC198 WG6 N0299 ISO/TC 198 WG6 N299 Antalya report

13) ISO/TC 198 WG6 N235, ISO/TC 198 WG6 N328 WG4+6 New Orleans Brief Report

14) ISO/WD 11140-6 Sterilization of health care products - Part 6 : Class2 indicators and process challenge devices for use in performance testing for steam sterilizers

15) ISO/TC198 N1175 Form06 11140-6 Result of voting on New Work Item Proposal

16）ISO/TS 17665-2：2009ヘルスケア製品の滅菌 - 湿熱－第 2 部：ISO 17665-1の適用の手引

17) ANSI/AAMI ST8; 2013, Hospital Steam Sterilization. 